\title{
THE CATALOG OF MAGNETIC STORMS FOR ODESSA MAGNETIC ANOMALY ZONE
}

\author{
L.I. Sobitnyak ${ }^{1}$, M.I. Ryabov ${ }^{1}$, A.L. Sukharev ${ }^{1}$, M.I. Orlyuk ${ }^{2}$, A.O. Romenets ${ }^{2}$, Yu.P.Sumaruk ${ }^{2}$ \\ ${ }^{1}$ URAN-4 Observatory, Radio-astronomical institute of NAS of Ukraine \\ ${ }^{2}$ Institute of geophysics NAS of Ukraine
}

ABSTRACT. On magnetic observatory "Odessa" since 1948 measurements of a magnetic field of Earth. At the same time measurements of three elements of a magnetic field are registered: horizontal component $(\mathrm{H})$, vertical component (Z) and inducement (D). On the basis of these data the catalog of magnetic storms in the 21 st century is made. In this release of the catalog during 2000-2009 date and time of the beginning and end of a storm, the storm duration, amplitude on three elements of a magnetic field are specified: H, Z, D, the characteristic of magnetic storms with the indication of the fissile periods. The magnetic station "Odessa" is located near a zone of a magnetic anomaly. For identification of reaction in the nature of the geomagnetic activity arising owing to existence of a magnetic anomaly comparison of geomagnetic disturbances at Odessa and Moscow was carried out.

Keywords: Solar activity, magnetic storms, magnetic storm catalog, magnetic anomaly.

АБСТРАКТ. На магнітній обсерваторії «Одеса» 3 1948 року ведуться вимірювання магнітного поля Землі. При цьому реєструються вимірювання трьох елементів магнітного поля: горизонтальної складової (H), вертикальної складової (Z) і схилення (D). На підставі цих даних складено каталог магнітних бур в XXI столітті. У цьому випуску каталогу, за період 2000-2009 роки, вказані дата і час початку і кінця бурі, тривалість бурі, амплітуда по трьох елементах магнітного поля: H, Z, D, характеристика магнітних бур із зазначенням активних періодів.

Моніторинг потоків потужних галактичних i позагалактичних радіоджерел виконується на радіотелескопі "УРАН-4" Одеської обсерваторії Радіоастрономічного інституту НАН України з 1987 р. i до тепер. У програму моніторингу входять радіогалактики 3С274, 3С405 і залишки наднових 3C144, 3С461. Спостереження радіоджерел проводилися окремими сеансами, в межах \pm 2 години до і після часу їх кульмінації. Час проходження радіоджерел 3С144, 3С274, 3С405 через діаграму спрямованості становило 40 хвилин (для кожного часового кута), для 3С461 - 60 хвилин. Загальний час добового моніторингу перевищує 13 годин. Зміни потоків випромінювання радіоджерел на декаметрових хвилях визначаються станом іоносфери під впливом космічної погоди. Цей каталог був складений, щоб визначити причини зміни потоку космічних радіоджерел за даними спостереження на радіотелескопі URAN-4 в Одеській обсерваторії Інституту радіоастрономії Національної академії наук України.

Магнітна обсерваторія «Одеса» розташована поблизу зони магнітної аномалії. Для виявлення ефектів «відгуку» в прояві характеру геомагнітних бур, які виникають внаслідок наявності магнітної аномалії, було проведено порівняння геомагнітних збурень на магнітних обсерваторіях "Одеса" та "Москва" (ІЗМІРАН). Зокрема виявлено що загальна тривалість магнітних бур за період 2000-2009 роки в Одесі довше, ніж в Москві. В більшості випадків тривалість потужних магнітних бур в Одесі більше, ніж в Москві.

Ключові слова: сонячна активність, магнітні бурі, каталог магнітних бур, магнітна аномалія.

The magnetic observatory «Odessa» was founded by the Novorossiysk Imperial University, in the territory of a botanical garden, at the beginning of the XX century. In 1936 it was transferred to the village of Stepanovka (near Odessa) by the Odessa State University. After World War 2th the station became to belong to the Institute of Geophysics. From 1948 to 2010, analog measurements of the Earth's magnetic field were conducted at the «Odessa» Magnetic Observatory. At the same time measurements of three elements of a magnetic field are registered: horizontal component $(\mathrm{H})$, vertical component $(\mathrm{Z})$ and inclination (D) [1]. Figure 1 presents a monthly review of the state of the magnetic field in November 2003. 


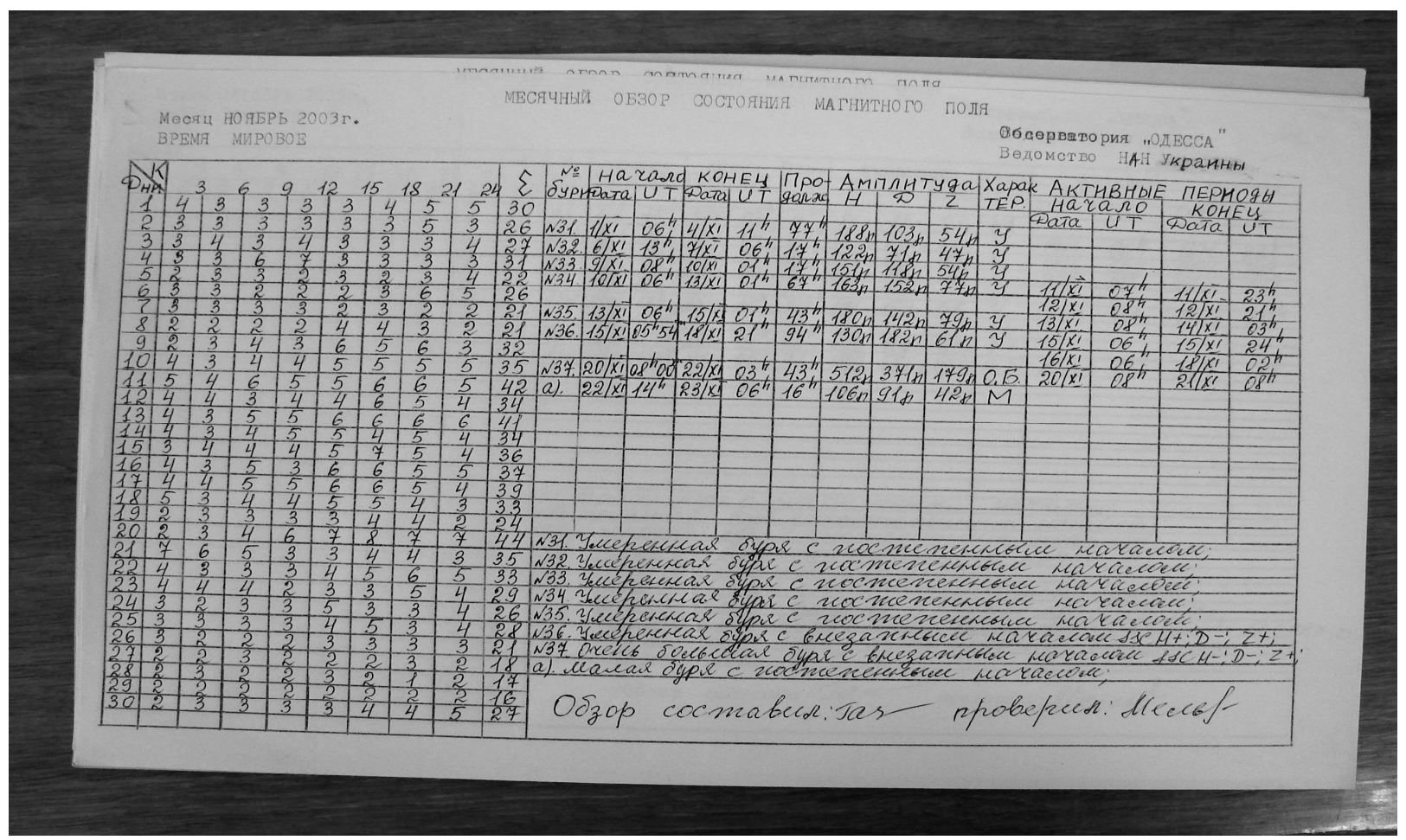

Figure 1: Review of the state of the magnetic field in November 2003

On the basis of data of magnetic observatory «Odessa» the catalog the magnetic storms is made. This issue of the catalog for 2000-2009 years include: date and time of the beginning and end of a storm, the storm duration, amplitude on three elements of a magnetic field are specified: H, Z, D, the characteristic of magnetic storms with the indication of the fissile periods.

As an example, data for the period January-March 2003 are presented at Table 1 . The total number of minor, moderate, strong and extreme storms shown in table 2 (for the period 2000-2009).

This catalog was compiled to identify the causes of changes in the flux of cosmic radio sources in the decameter range according to monitoring observations at the URAN-4 radio telescope at the Odessa Observatory of the Radio Astronomy Institute of the National Academy of Sciences of Ukraine, which have been conducted since 1987.

The magnetic observatory "Odessa" is situated near the intensive magnetic anomaly. The identification of the magnetic anomaly influence on geomagnetic activity comparison of characteristics of magnetic storms at according to the magnetic observatorys "Odessa" and "Moscow" was carried out. The total duration of all magnetic storms throughout the year in Odessa is more than in Moscow (IZMIRAN) (Figure 2).

Table 3 provides information on the duration of individual magnetic storms in the magnetic observatories "Odessa" and IZMIRAN for 2001-2003. With a greater amplitude of magnetic field disturbance in the IZMIRAN magnetic observatory, the duration of magnetic storms in Odessa is longer.

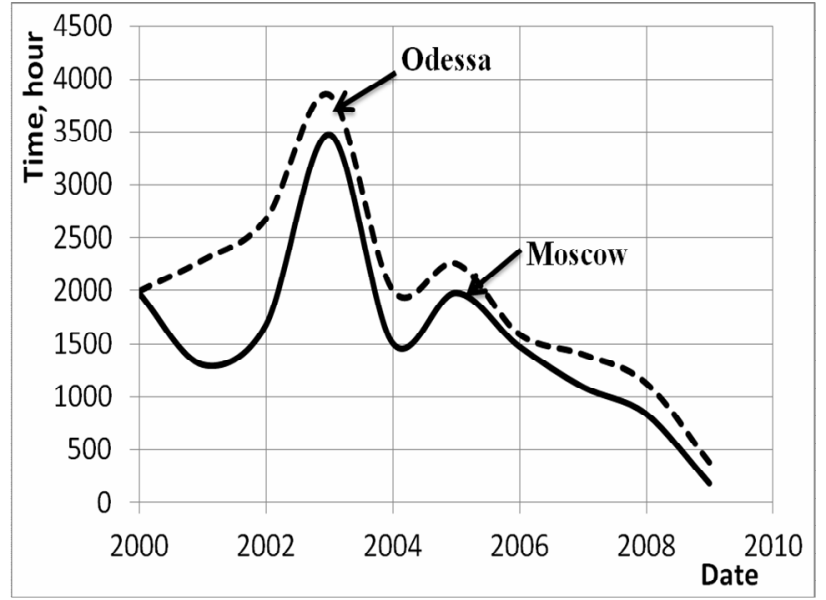

Figure 2: The total annual duration of magnetic storms according to the magnetic observatorys "Odessa" and "Moscow" (2000-2010).

\section{Conclusion}

On the basis of data of magnetic observatory «Odessa» the catalog the magnetic storms is made. This issue of the catalog for 2000-2009 years include: date and time of the beginning and end of a storm, the storm duration, amplitude on three elements of a magnetic field are specified: H, Z, D, the characteristic of magnetic storms.

1. The comparison duration of magnetic storms according to the magnetic observatory "Odessa" is longer than at "Moscow" (IZMIRAN).

2. It is planned to create a catalog of magnetic storms according to the Odessa station for the entire monitoring period of space radio sources at the RT URAN-4 in order 
Table 1: Digital catalog of magnetic storms and their characteristics

\begin{tabular}{|c|c|c|c|c|c|c|c|c|c|c|c|c|c|}
\hline \multirow{2}{*}{\multicolumn{2}{|c|}{ Beginning }} & \multirow{2}{*}{\multicolumn{2}{|c|}{ End }} & \multirow{3}{*}{$\begin{array}{c}\text { Duration, } \\
\text { h }\end{array}$} & \multirow{2}{*}{\multicolumn{3}{|c|}{ Amplitude }} & \multirow{3}{*}{$\begin{array}{l}\text { Storm } \\
\text { class }\end{array}$} & \multicolumn{4}{|c|}{ Active periods } & \multirow{3}{*}{ Comment } \\
\hline & & & & & & & & & \multicolumn{2}{|l|}{ begin } & \multicolumn{2}{|l|}{ end } & \\
\hline date & UT & date & UT & & $\mathbf{H}$ & D & $\mathbf{Z}$ & & date & UT & date & UT & \\
\hline 03.01 .2003 & $12: 00$ & 04.01 .2003 & $0: 00$ & 36 & 95 & 94 & 36 & minor & & & & & $\begin{array}{l}\text { Minor storm with the } \\
\text { gradual beginning }\end{array}$ \\
\hline 18.01 .2003 & $6: 00$ & 20.01 .2003 & $6: 00$ & 48 & 105 & 64 & 39 & minor & & & & & $\begin{array}{l}\text { Minor storm with the } \\
\text { gradual beginning }\end{array}$ \\
\hline 20.01 .2003 & $10: 00$ & 23.01 .2003 & $4: 00$ & 66 & 98 & 68 & 38 & minor & & & & & $\begin{array}{l}\text { Minor storm with the } \\
\text { gradual beginning }\end{array}$ \\
\hline 29.01 .2003 & 9:00 & 30.01 .2003 & 20:00 & 35 & 116 & 124 & 42 & moderate & & & & & $\begin{array}{l}\text { Moderate storm with the } \\
\text { gradual beginning }\end{array}$ \\
\hline 01.02 .2003 & $15: 00$ & 05.02 .2003 & $3: 00$ & 84 & 176 & 145 & 82 & moderate & 01.02 .2003 & 18:00 & 03.02 .2003 & $2: 00$ & $\begin{array}{l}\text { Moderate storm with the } \\
\text { gradual beginning }\end{array}$ \\
\hline & & & & & & & & & 03.02 .2003 & $12: 00$ & 04.02 .2003 & $12: 00$ & \\
\hline 08.02 .2003 & 7:00 & 09.02 .2003 & $3: 00$ & 20 & 75 & 70 & 26 & minor & & & & & $\begin{array}{l}\text { Minor storm with the } \\
\text { gradual beginning }\end{array}$ \\
\hline 12.02 .2003 & $8: 00$ & 13.02 .2003 & $1: 00$ & 17 & 83 & 74 & 26 & minor & & & & & $\begin{array}{l}\text { Minor storm with the } \\
\text { gradual beginning }\end{array}$ \\
\hline 13.02 .2003 & $21: 00$ & 15.02 .2003 & $21: 00$ & 48 & 80 & 105 & 35 & minor & 14.02 .2003 & 9:00 & 15.02 .2003 & 18:00 & $\begin{array}{l}\text { Minor storm with the } \\
\text { gradual beginning }\end{array}$ \\
\hline 16.02 .2003 & $6: 00$ & 17.02 .2003 & 2:00 & 20 & 86 & 62 & 32 & minor & & & & & $\begin{array}{l}\text { Minor storm with the } \\
\text { gradual beginning }\end{array}$ \\
\hline 26.02.2003 & $6: 00$ & 28.02 .2003 & $1: 00$ & 43 & 106 & 114 & 48 & moderate & & & & & $\begin{array}{l}\text { Moderate storm with the } \\
\text { gradual beginning }\end{array}$ \\
\hline 28.02 .2003 & $6: 00$ & 01.03 .2003 & $3: 00$ & 21 & 93 & 85 & 42 & minor & & & & & $\begin{array}{l}\text { Minor storm with the } \\
\text { gradual beginning }\end{array}$ \\
\hline 03.03 .2003 & $15: 00$ & 05.03 .2003 & $3: 00$ & 36 & 92 & 131 & 57 & moderate & & & & & $\begin{array}{l}\text { Moderate storm with the } \\
\text { gradual beginning }\end{array}$ \\
\hline 05.03 .2003 & 9:00 & 07.03 .2003 & $12: 00$ & 51 & 103 & 96 & 46 & minor & & & & & $\begin{array}{l}\text { Minor storm with the } \\
\text { gradual beginning }\end{array}$ \\
\hline 20.03 .2003 & $6: 00$ & 22.03 .2003 & $2: 00$ & 44 & 119 & 101 & 50 & moderate & & & & & $\begin{array}{l}\text { Moderate storm with the } \\
\text { gradual beginning }\end{array}$ \\
\hline 22.03 .2003 & 19:00 & 24.03 .2003 & $2: 00$ & 31 & 106 & 85 & 32 & minor & & & & & $\begin{array}{l}\text { Minor storm with the } \\
\text { gradual beginning }\end{array}$ \\
\hline 28.03 .2003 & $16: 00$ & 31.03 .2001 & $3: 00$ & 59 & 98 & 124 & 81 & moderate & & & & & $\begin{array}{l}\text { Moderate storm with the } \\
\text { gradual beginning }\end{array}$ \\
\hline 31.03 .2003 & $6: 00$ & 01.04 .2003 & $4: 00$ & 22 & 127 & 111 & 62 & moderate & & & & & $\begin{array}{l}\text { Moderate storm with the } \\
\text { gradual beginning }\end{array}$ \\
\hline
\end{tabular}


Table 2: Amount of magnetic storms in the catalog for 2000-2009

\begin{tabular}{|c|c|c|c|c|c|c|c|c|c|c|}
\hline Storm class & 2000 & 2001 & 2002 & 2003 & 2004 & 2005 & 2006 & 2007 & 2008 & 2009 \\
\hline minor & 25 & 31 & 39 & 38 & 31 & 30 & 32 & 34 & 28 & 11 \\
\hline moderate & 16 & 27 & 21 & 36 & 11 & 16 & 9 & 5 & 4 & 0 \\
\hline strong & 5 & 4 & 4 & 1 & 4 & 5 & 1 & 0 & 0 & 0 \\
\hline extreme & 3 & 6 & 2 & 2 & 2 & 4 & 0 & 0 & 0 & 0 \\
\hline
\end{tabular}

Table 3: The duration of the most intense magnetic storms according to the magnetic observatories "Odessa" and IZMIRAN

\begin{tabular}{|c|c|c|c|c|c|c|c|c|}
\hline \multicolumn{4}{|c|}{2001} & \multicolumn{3}{c|}{$\mathbf{2 0 0 2}$} & \multicolumn{3}{c|}{2003} \\
\hline Date & Odessa & Moscow & Date & Odessa & Moscow & Date & Odessa & Moscow \\
\hline 19.03 .2001 & 38 & 40 & 10.01 .2002 & 89 & 30 & 24.04 .2003 & 108 & 41 \\
\hline 28.03 .2001 & 35 & 28 & 17.04 .2002 & 43 & 21 & 26.06 .2003 & 102 & 41 \\
\hline 31.03 .2001 & 70 & 9 & 19.04 .2002 & 39 & 9 & 15.07 .2003 & 52 & 2 \\
\hline 08.04 .2001 & 35 & 24 & 11.05 .2002 & 30 & 22 & 28.07 .2003 & 157 & 40 \\
\hline 11.04 .2001 & 29 & 18 & 23.05 .2002 & 12 & 9 & 20.08 .2003 & 116 & 56 \\
\hline 18.04 .2001 & 34 & 10 & 01.08 .2002 & 88 & 26 & 15.09 .2003 & 127 & 56 \\
\hline 17.08 .2001 & 36 & 8 & 01.10 .2002 & 45 & 61 & 16.10 .2003 & 91 & 40 \\
\hline 21.10 .2001 & 48 & 4 & 03.10 .2002 & 65 & 50 & 15.11 .2003 & 94 & 2 \\
\hline 05.11 .2001 & 62 & 40 & 02.11 .2002 & 125 & 20 & 20.11 .2003 & 43 & 9 \\
\hline
\end{tabular}

to identify manifestations of geomagnetic disturbances during radio astronomical observations and their contribution to changes in radio source fluxes on decameter waves.

3. These studies will also be supplemented by a comparative analysis of the manifestation of magnetic storms of the magnetic anomaly zone in Odessa and data from other magnetic observatories in Ukraine.

\section{References}

1. Orliuk M., Sumaruk Yu., Sumaruk T., Romenets A., Melnychuk I.: 2009, in The IAGA11th Scientific Assembly in Sopron, Hungary, iaga2009sopron.hu\ iaga_abstracts.
2. Russel, C. T. and Mcpherron, R. L., 1973. Semiannual Variation of Geomagnetic Activity. J. Geophys. Res. Space Phys. vol. 78, is. 1, pp. 92-108. DOI: 10.1029/JA078i001p000922.

3. Plasma heliogeophysics. Moscow: Fizmatlit, 2008, 1-2, 560.

4. Miroshnichenko L.I., Physics of the Sun and solarterrestrial connections. M.: University book, 2011, 174 p.

5. Obridko V.N., Nagovitsyn Y.A. Solar activity, cyclicity and prediction methods. St. Petersburg: BBM, 2017, 467p.

6. BRUZEK, A. and DURRANT, C. J., eds., 1977 Illustrated glossary for solar and solar-terrestrial physics. Dordrecht, Boston: D. Reidel Pub. Co. 